\title{
Article \\ Chemical Profile of the Volatile Constituents and Antimicrobial Activity of the Essential Oils from Croton adipatus, Croton thurifer, and Croton collinus
}

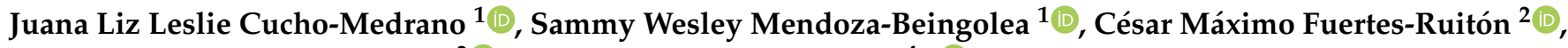 \\ María Elena Salazar-Salvatierra ${ }^{3}(\mathbb{D})$ and Oscar Herrera-Calderon ${ }^{4, *}(\mathbb{D}$ \\ 1 Faculty of Pharmacy and Biochemistry, Universidad Nacional Mayor de San Marcos, Jr. Puno 1002, \\ Lima 15001, Peru; liz.cumed@gmail.com (J.L.L.C.-M.); sammy.mendoza@unmsm.edu.pe (S.W.M.-B.) \\ 2 Institute for Research in Pharmaceutical Sciences and Natural Resources, Faculty of Pharmacy and \\ Biochemistry, Universidad Nacional Mayor de San Marcos, Jr. Puno 1002, Lima 15001, Peru; \\ cfuertesr@unmsm.edu.pe \\ 3 Research Institute in Biological Chemistry, Microbiology and Biotechnology, Faculty of Pharmacy and \\ Biochemistry, Universidad Nacional Mayor de San Marcos, Jr. Puno 1002, Lima 15001, Peru; \\ msalazars@unmsm.edu.pe \\ 4 Department of Pharmacology, Bromatology and Toxicology, Faculty of Pharmacy and Biochemistry, \\ Universidad Nacional Mayor de San Marcos, Jr. Puno 1002, Lima 15001, Peru \\ check for \\ updates \\ * Correspondence: oherreraca@unmsm.edu.pe; Tel.: +51-956-550-510
}

Citation: Cucho-Medrano, J.L.L.; Mendoza-Beingolea, S.W.;

Fuertes-Ruitón, C.M.;

Salazar-Salvatierra, M.E.;

Herrera-Calderon, O. Chemical

Profile of the Volatile Constituents

and Antimicrobial Activity of the

Essential Oils from Croton adipatus, Croton thurifer, and Croton collinus. Antibiotics 2021, 10, 1387. https:// doi.org/10.3390/antibiotics10111387

Academic Editors: Carla Sabia and Ramona Iseppi

Received: 19 October 2021

Accepted: 10 November 2021

Published: 12 November 2021

Publisher's Note: MDPI stays neutral with regard to jurisdictional claims in published maps and institutional affiliations.

Copyright: (c) 2021 by the authors. Licensee MDPI, Basel, Switzerland. This article is an open access article distributed under the terms and conditions of the Creative Commons Attribution (CC BY) license (https:// creativecommons.org/licenses/by/ $4.0 /)$.

\begin{abstract}
The aim of this study was to determine the volatile phytochemical constituents and evaluate the antimicrobial activity of the essential oils of the leaves from Croton adipatus, Croton thurifer, and Croton collinus. Essential oils were extracted by hydro-distillation using the Clevenger extractor and the phytochemical analysis was determined by Gas chromatography-Mass Spectrometry (GC-MS). The antimicrobial activity was assessed using the agar diffusion and colorimetric broth microdilution methods against Staphylococcus aureus ATCC 25923, Bacillus subtilis ATCC 6633, Escherichia coli ATCC 25922, Pseudomonas aeruginosa ATCC 9027, and Candida albicans ATCC The essential oils from $C$. adipatus, $C$. thurifer, and $C$ collinus had 46, 38, and 35 volatile constituents respectively. The main compounds determined in C. adipatus were $\beta$-myrcene $(18.34 \%)$, while in C. collinus was $\beta$-caryophyllene (44.7\%), and in $C$. thurifer was an unknown component $\left(\mathrm{C}_{10} \mathrm{H}_{16}: 22.38 \%\right)$. Essential oil of $C$. adipatus showed a MIC against B. subtilis $(286.4 \mu \mathrm{g} / \mathrm{mL})$ and C. albicans $(572.8 \pm 0 \mu \mathrm{g} / \mathrm{mL})$; C. thurifer against $S$. aureus $(296.1 \pm 0 \mu \mathrm{g} / \mathrm{mL})$ and B. subtilis $(148 \pm 0 \mu \mathrm{g} / \mathrm{mL})$; and C. collinus against B. subtilis $(72 \pm 0 \mu \mathrm{g} / \mathrm{mL})$ and C. albicans $(576.2 \pm 0 \mu \mathrm{g} / \mathrm{mL})$. The three essential oils of Croton species demonstrated in vitro antimicrobial activity against a strain of bacteria or fungi.
\end{abstract}

Keywords: antimicrobial; antifungal; colorimetric microdilution; volatile oil; medicinal plants; gram positive; gram negative

\section{Introduction}

In recent decades, the emergence of antimicrobial resistance has generated alarm in the health system. Several factors have contributed to the evolution of antimicrobial resistance, including microbial adaptation through selective biochemical processes, self-medication in the community, and the shortage in the development of new antimicrobial molecules which leads to choices of antimicrobial drugs with an inadequately broad spectrum and side effects, making access to essential antimicrobials more expensive [1]. On the other hand, the medicinal properties of plants have been recognized and have generated a great deal of interest due to their easy access, low toxicity, economic viability and easy preparation forms such as macerations, decoctions, infusions, tinctures, and essential oils [2]. Hence, there are many alternative therapies that include the extended use of essential oils, which are considered a set of volatile secondary metabolites synthesized in 
different plant organs as a response to adverse environmental conditions, and the attack of herbivores [3]. Several research studies attribute different medicinal properties to essential oils such as antibacterial, antifungal, antiviral, antioxidant, anti-inflammatory, anticancer, antidiabetic, antiparasitic, insecticidal, antimutagenic, antiprotozoal, immunomodulatory, and antitumor [4].

Peru is a megadiverse country due to its geographical location; the Peruvian flora comprises around 25,000 species that are distributed in the different ecological levels. An important part of the flora grows in the inter-Andean valleys and are exposed to a high solar radiation and low temperatures [5]. Among the plants belonging to the Euphorbiaceae family, Peru presents 61 genera, and 323 species of which the Croton genus is the most numerous in endemic species [6]. Additionally, Croton is the second most abundant genus of the Euphorbiaceae family due to its variety and richness, which is why it includes more than 1200 species. The Croton genus presents a cosmopolitan distribution both in the tropics and subtropics throughout the world, primarily in arid and semi-arid zones [7,8]; however, a wide variety are found in Madagascar, Brazil, and the Caribbean [9]. In Peru they are found in different regions between altitudes ranging from 110 to 3200 meters above sea level.

The Croton genus is important locally for its different medicinal properties, i.e., their leaves are used as healing, hemostatic, antidiarrheal, anti-inflammatory, and antiseptic agents. They are used for conditions such as uterine colic, gastrointestinal ulcers, urinary retention, antepartum vaginal baths, postpartum hemorrhages, skin diseases, and for the control of fever associated with gastrointestinal illnesses [10]. Essential oils from Croton species have presented several volatile constituents as fingerprint, which might be related to its antimicrobial activity, i.e., C. ceanothifolius showed bicyclogermacrene $(26.3 \%)$, germacrene D (14.7\%), and E-caryophyllene (11.7\%) as major components [11], in $C$. heliotropiifolius were found $\beta$-caryophyllene as the major constituent followed by bicyclogermacrene, germacrene-D, limonene, and 1,8-cineole [12], in C. argyrophyllus had bicyclogermacrene (38.42\%), (Z)-caryophyllene (14.06\%), epi-longipinanol (9.78\%), and germacrene B (9.1\%) [13], in C. zenhtneri, C. nepetaefolius, and C. sonderianus were transanethole (94.09\%), methyl eugenol (48.47\%), and $\beta$-phellandrene (18.21\%) respectively [14], finally in C. pulegiodorus were identified $\beta$-caryophyllene $(20.96 \%)$, bicyclogermacrene $(16.89 \%)$, germacrene-D (10.55\%), $\tau$-cadinol (4.56\%), and $\beta$-copaen- 4 - $\alpha$-ol $(4.35 \%)$ [15].

Otherwise, Croton adipatus, Croton thurifer, and Croton collinus are known for their antimicrobial properties; however, such properties have not been scientifically proven as well as their chemical composition. Thus, the main aim in this study was to determine the chemical composition and the in-vitro antimicrobial activity of the essential oils from Croton adipatus, Croton thurifer, and Croton collinus against Staphylococcus aureus ATCC 25923, Bacillus subtilis ATCC 6633, Escherichia coli ATCC 25922, Pseudomonas aeruginosa ATCC 9027, and Candida albicans ATCC 10231.

\section{Results and Discussion}

\subsection{Phytochemical Screening of the Volatile Components of the Essential Oils from Croton Species}

The extraction yields of the essential oils of Croton adipatus, Croton thurifer, and Croton collinus were $0.47 \pm 0.01 \%, 0.07 \pm 0.005 \%$, and $0.06 \pm 0.001 \%$, respectively; being the first reports in these species (Supplementary Materials: Table S1). Other studies reported yield percentages in C. borarium leaves and C. geayi leaves values of $0.68 \%$ and $0.72 \%$, respectively [16], C. zambesicus (leaves: 0.29\%) [17], C. cajucara [18](leaves: $0.4 \%$ and 0.65\%), C. heterocalyx (leaves: 0.45\%) [19], C. pullei (stems: 0.06\%, leaves: 0.5\%) [20], C. campestris (branches: 0.02\%; leaves: 0.04\%) [21] C. blanchetianus (leaves: 0.7\%) [22], C. oblongifolius (bark: 0.9\%) [23], and C. hieronymi (roots: $0.06 \%$; leaves: $0.07 \%$ ) [24]. In this study, $C$. adipatus, $C$. thurifer, and $C$. collinus showed extraction yields similar to the average reported in other species of the Croton genus. Several factors such as soil composition, climate, geographic location, variety of the species, vegetative state, seasonal variation, organ used for extraction, collection period, storage, drying methods, extraction processes, 
and others might be decisive in the composition, proportion, and quantity in the yield rate of essential oils [25].

Regarding to the determination of the volatile phytochemicals by GC-MS of the essential oil of $C$. adipatus, 46 compounds were determined (Table 1; Supplementary Materials: Figures S1 and S2, Table S2), of which monoterpenes represent 72.73\% (monoterpenes hydrocarbon $69.76 \%$; oxygenated monoterpenes $2.97 \%$ ), followed by sesquiterpenes $18.82 \%$ (sesquiterpenes hydrocarbon $16.06 \%$; oxygenated sesquiterpenes $2.76 \%$ ), phenylpropane derivatives $0.24 \%$, and others $8.21 \%$. $\beta$-myrcene was the most abundant component with $18.34 \%$ followed by $\alpha$-thujene at $12.69 \%$, D-limonene at $10.94 \%, \alpha$-phellandrene at $8.19 \%$, and $\beta$-elemene at $6.47 \%$. These results are the first report of the chemical composition; the concentrations of $\beta$-myrcene $(18.34 \%)$ and $\alpha$-thujene $(12.69 \%)$ are the major ones found in regard to other species of the Croton genus. A similar concentration of D-limonene $(10.94 \%)$ was also found by De Almeida et al. in C. campestris (9.7\%) [21], and a lower concentration in C. geayi $(22.92 \%)$ [16].

For the essential oil of $C$. thurifer, 35 compounds were determined (Table 1; Supplementary Materials: Figures S3 and S4, Table S3). The composition of sesquiterpenes were predominantly abundant, at $62.26 \%$ (sesquiterpenes hydrocarbon $33.88 \%$; oxygenated sesquiterpenes $28.38 \%$ ), followed by monoterpenes at $35.39 \%$ (monoterpenes hydrocarbon $34.88 \%$; oxygenated monoterpenes $0.51 \%$ ) and other at $2.35 \%$. The unknown monoterpenes component with $22.38 \%\left(\mathrm{C}_{10} \mathrm{H}_{16}\right.$; Rt: 18.57) was the most abundant component, followed by another unknown sesquiterpene component $21.8 \%\left(\mathrm{C}_{15} \mathrm{H}_{26} \mathrm{O}\right.$; Rt: 53.7), $\beta$-elemene $11.87 \%$, germacrene D 10.22\%. Moreno et al. reported in C. heterocalyx leaves, $\beta$-elemene $(8.2 \%)$, germacrene D (12.5\%) [19] and De Araújo reported C. rhamnifolius stems (17.28\%) [26]. On the other hand, Dai et al. in C. cascarilloides (6.0\%) [27] and Turiel et al. in C. draconoides $(9.0 \%)$ [28].

In C. collinus essential oil, 38 compounds were determined (Table 1; Supplementary Materials: Figures S5 and S6, Table S4). Sesquiterpenes 70.26\% were obtained predominantly (hydrocarbon sesquiterpenes $68.25 \%$; oxygenated sesquiterpenes $2.51 \%$ ), followed by monoterpenes $28.03 \%$ (hydrocarbon monoterpenes $27.44 \%$; oxygenated monoterpenes $0.59 \%$ ) and others $1.21 \%$. The major component was $\beta$-caryophyllene with $44.7 \%$, followed by D-limonene $8.73 \%$, $\beta$-thujene $6.96 \%, \beta$-myrcene $6.79 \%$, and $\beta$-elemene $6.7 \%$. $\beta$ caryophyllene was the highest abundant volatile component among Croton species. However, other studies reported lower concentrations of this component ( $\beta$-caryophyllene): in C. antanosiensis leaves (28.23\%), C. decaryi leaves (26.65\%) [29], C. rhamnifolioides (6.33\%) [30], C. huberi (18.3\%) [31], C. conduplicatus (7.8\%) [32], C. trinitatis (15.3\%) [33], C. isabelli (14.3\%), and C. pallidulus $(11.5 \%)$ [34].

Other studies of the Croton genus reported other major compounds according to the organ of the plant such as in C. zambesicus leaves and stems (1,8-cineole $27.07 \%$ and cymene 13.80\%) [35]; C. zehntneri leaves (estragole 93.61\% and 84.7\%) [36], C. hieronymi leaves (camphor 13.9\%) [24], C. hieronymi root ( $\gamma$-asarone 25.7\%) [24], C. oblongifolius bark (terpinen-4-ol 17.8\%) [23]; C. pullei leaves (linalol 24.9\%) [20], C. greveanus leaves (1.8 cineol $40.40 \%$ and linalol 23.81\%); C. borarium leaves ( $\beta$-phellandrene 39. $72 \%$ and $\alpha$-terpineol $25.12 \%$ ); and in C. geayi leaves ( $\beta$-pinene $28.74 \%$ and limonene $22.92 \%$ ) [16]. The diversity of the qualitative and quantitative characteristics of the components of essential oils in C. adipatus, C. thurifer, and C. collinus can be explained due to many factors reported by other authors such as the harvesting season, extraction method, drying method, drying time, geographical conditions, genetic variability, soil composition, plant organ, climate, drought condition, vegetative state cycle, plant nutrition, application of fertilizers, stress during growth, and post-harvest storage [25,37,38]. 
Table 1. Chemical composition of C. adipatus, C. thurifer, and C. collinus essential oil.

\begin{tabular}{|c|c|c|c|c|c|}
\hline \multirow{2}{*}{$\mathbf{N}^{\circ}$} & \multirow{2}{*}{ Chemicals } & \multirow{2}{*}{$\begin{array}{c}\text { C. adipatus } \\
\%\end{array}$} & \multirow{2}{*}{$\begin{array}{c}\text { C. thurifer } \\
\%\end{array}$} & \multirow{2}{*}{$\begin{array}{c}\text { C. collinus } \\
\% \\
\end{array}$} & \multirow{2}{*}{ Chemical Group } \\
\hline & & & & & \\
\hline 1 & Isobutyl isobutyrate & 0.2 & & & Carboxylic acid esters \\
\hline 2 & $\alpha$-Thujene & 12.69 & 1.7 & 0.17 & Monoterpene hydrocarbon \\
\hline 3 & $\alpha$-Pinene & 3.64 & 0.96 & 0.41 & Monoterpene hydrocarbon \\
\hline 4 & Sabinene & 3.17 & 1.2 & 0.31 & Monoterpene hydrocarbon \\
\hline 5 & $\beta$-Pinene & 1.55 & 0.38 & 0.36 & Monoterpene hydrocarbon \\
\hline 6 & $\beta$-Myrcene & 18.34 & & 6.79 & Monoterpene hydrocarbon \\
\hline 7 & Unknown $\left(\mathrm{C}_{10} \mathrm{H}_{16}\right)$ & & 22.38 & & Monoterpene hydrocarbon \\
\hline 8 & $\alpha$-Phellandrene & 8.19 & 3.3 & 0.61 & Monoterpene hydrocarbon \\
\hline 9 & Isoamyl isobutyrate & 0.53 & 0.99 & & Fatty acid ester \\
\hline 10 & $\alpha$-Terpinene & 0.56 & & & Monoterpene hydrocarbon \\
\hline 11 & p-Cymene & & 0.36 & 0.29 & Monoterpene hydrocarbon \\
\hline 12 & o-Cymene & 1.38 & & & Monoterpene hydrocarbon \\
\hline 13 & D-Limonene & 10.94 & 1.94 & 8.73 & Monoterpene hydrocarbon \\
\hline 14 & $\beta$-Thujene & & & 6.96 & Monoterpene hydrocarbon \\
\hline 15 & $\beta$-Phellandrene & 4.94 & 1.44 & & Monoterpene hydrocarbon \\
\hline 16 & Eucalyptol & 0.7 & 0.51 & & Oxygenated monoterpenes \\
\hline 17 & $\gamma$-Terpinene & & 0.88 & 2.1 & Monoterpene hydrocarbon \\
\hline 18 & cis-Ocimene & 0.43 & & 0.35 & Monoterpene hydrocarbon \\
\hline 19 & $\tau$-Terpinene & 3.21 & & & Monoterpene hydrocarbon \\
\hline 20 & $\beta$-Terpineol & 0.44 & & & Alcohol monoterpene \\
\hline 21 & Terpinolene & 0.16 & & 0.17 & Monoterpene hydrocarbon \\
\hline 22 & $\beta$-Linalool & 0.4 & & & Oxygenated monoterpenes \\
\hline 23 & 1,6-Dimethylhepta-1,3,5-triene & 0.47 & & & Alkene \\
\hline 24 & 4-Terpineol & 0.74 & & & Oxygenated monoterpenes \\
\hline 25 & 2-Decanone & 0.17 & & & ketone \\
\hline 26 & $\alpha$-Terpineol & 0.12 & & & Oxygenated monoterpenes \\
\hline 27 & 2-Undecanone & 2.16 & & 0.72 & ketone \\
\hline 28 & 2-Dodecanone & 4.56 & & & ketone \\
\hline 29 & 2-Carene & 0.56 & & & Monoterpene hydrocarbon \\
\hline 30 & 1,5,5-Trimethyl-6-methylene-cyclohexene & & & 0.19 & Monoterpene hydrocarbon \\
\hline 31 & Copaene & & 0.44 & 0.28 & Monoterpene hydrocarbon \\
\hline 32 & Unknown I $\left(\mathrm{C}_{15} \mathrm{H}_{24}\right)$ & 0.15 & & 0.23 & Sesquiterpene hydrocarbon \\
\hline 33 & $\begin{array}{l}\text { 1-Ethenyl-1-methyl-2,4-bis-(1-methylethenyl)- } \\
\text { cyclohexane }\end{array}$ & & 0.34 & & Sesquiterpene hydrocarbon \\
\hline 34 & Unknown II $\left(\mathrm{C}_{15} \mathrm{H}_{24}\right)$ & & & 0.23 & Sesquiterpene hydrocarbon \\
\hline 35 & $\beta$-Elemene & 6.47 & 11.87 & 6.7 & Sesquiterpene hydrocarbon \\
\hline 36 & 2-Ethyl-1,3-dimethyl-Benzene & 0.24 & & & Benzene \\
\hline 37 & Cyperene & & 0.69 & 1.03 & Sesquiterpene hydrocarbon \\
\hline 38 & $\beta$-Caryophyllene & 0.28 & 1.95 & 44.7 & Sesquiterpene hydrocarbon \\
\hline 39 & $\delta$-Elemene & 0.71 & & & Sesquiterpene hydrocarbon \\
\hline 40 & Geranyl acetone & 0.16 & & 0.59 & Monoterpene ketone \\
\hline 41 & Unknown III $\left(\mathrm{C}_{15} \mathrm{H}_{24}\right)$ & & 0.74 & & Sesquiterpene hydrocarbon \\
\hline 42 & Aromadendrene & & 1.25 & 0.23 & Sesquiterpene hydrocarbon \\
\hline 43 & $\alpha$-Caryophyllene & & 0.3 & 3.73 & Sesquiterpene hydrocarbon \\
\hline 44 & Valencene & & & 0.53 & Sesquiterpene hydrocarbon \\
\hline 45 & $\alpha$-Elemene & & 0.52 & & Sesquiterpene hydrocarbon \\
\hline 46 & Unknown IV $\left(\mathrm{C}_{15} \mathrm{H}_{24}\right)$ & & 1.43 & & Sesquiterpene hydrocarbon \\
\hline 47 & $\alpha$-Curcumene & & & 0.39 & Sesquiterpene hydrocarbon \\
\hline 48 & $\alpha$-Muurolene & 0.45 & & & Sesquiterpene hydrocarbon \\
\hline 49 & Unknown $\mathrm{V}\left(\mathrm{C}_{15} \mathrm{H}_{24}\right)$ & & 0.59 & & Sesquiterpene hydrocarbon \\
\hline 50 & Germacrene D & 4.78 & 10.22 & 2.51 & Sesquiterpene hydrocarbon \\
\hline 51 & $\alpha$-Selinene & 0.39 & & 0.21 & Sesquiterpene hydrocarbon \\
\hline 52 & Eremophilene & & 0.67 & & Sesquiterpene hydrocarbon \\
\hline 53 & $\beta$-Cubebene & & & 0.22 & Sesquiterpene hydrocarbon \\
\hline 54 & Bicyclogermacrene & 1.24 & & 3.88 & Sesquiterpene hydrocarbon \\
\hline 55 & Geranil isobutyrate & 0.41 & & & Carboxylic ester monoterpene \\
\hline 56 & Unknown I $\left(\mathrm{C}_{15} \mathrm{H}_{26} \mathrm{O}\right)$ & & 3.73 & & Sesquiterpene hydrocarbon \\
\hline 57 & Unknown II $\left(\mathrm{C}_{15} \mathrm{H}_{26} \mathrm{O}\right)$ & & 1.62 & & Sesquiterpene hydrocarbon \\
\hline 58 & $\delta$-Cadinene & 0.48 & 1.26 & 1.96 & Sesquiterpene hydrocarbon \\
\hline 59 & $\alpha$-Muurolene & & & 0.51 & Sesquiterpene hydrocarbon \\
\hline 60 & Unknown VII $\left(\mathrm{C}_{15} \mathrm{H}_{24}\right)$ & 0.31 & & 0.76 & Sesquiterpene hydrocarbon \\
\hline 61 & Elemol & 1.61 & & & Oxygenated sesquiterpene \\
\hline 62 & Unknown VIII $\left(\mathrm{C}_{15} \mathrm{H}_{24}\right)$ & 0.69 & & & Sesquiterpene hydrocarbon \\
\hline 63 & (-)-Spatulenol & & & 0.58 & Oxygenated sesquiterpene \\
\hline 64 & Unknown $\left(\mathrm{C}_{15} \mathrm{H}_{24} \mathrm{O}\right)$ & & & 0.89 & n.d. \\
\hline 65 & Unknown III $\left(\mathrm{C}_{15} \mathrm{H}_{26} \mathrm{O}\right)$ & 0.51 & 0.64 & & n.d. \\
\hline 66 & Unknown $\left(\mathrm{C}_{15} \mathrm{H}_{22} \mathrm{O}\right)$ & & 0.31 & & n.d. \\
\hline 67 & $\beta$-Maaliene & 0.11 & & & Sesquiterpene hydrocarbon \\
\hline 68 & Unknown $\left(\mathrm{C}_{9} \mathrm{H}_{14} \mathrm{O}\right)$ & & 1.15 & & n.d. \\
\hline 69 & $\tau$-Muurolene & & & 0.15 & Sesquiterpene hydrocarbon \\
\hline 70 & Unknown IV $\left(\mathrm{C}_{15} \mathrm{H}_{26} \mathrm{O}\right)$ & 0.1 & 21.8 & & n.d. \\
\hline 71 & $\tau$-Muurolol & 0.16 & & 0.34 & Oxygenated sesquiterpene \\
\hline 72 & $\alpha$-Cadinol & & & 0.73 & Oxygenated sesquiterpene \\
\hline 73 & Unknown $\mathrm{V}\left(\mathrm{C}_{15} \mathrm{H}_{26} \mathrm{O}\right)$ & 0.38 & 0.28 & & n.d. \\
\hline 74 & Heptadecane & 0.12 & 0.26 & 0.49 & Alkane \\
\hline & Total of identified compounds (\%) & 100.00 & 100.00 & 100.00 & \\
\hline
\end{tabular}


On the other hand, differences in the qualitative and quantitative compositions of the obtained essential oils have been observed in Table As shown in the Venn diagram (Figure 1), $\alpha$-thujene, $\alpha$-pinene, sabinene, $\beta$-pinene, $\alpha$-phellandrene, D-limonene, $\beta$-elemene, $\beta$-caryophyllene, germacrene $D, \alpha$-cadinene, and heptadecane were shared by all three species, for a total of 11 compounds. Additionally, 18 compounds were uniquely identified in C. adipatus, 11, and 10 in C thurifer and C. collinus, respectively.

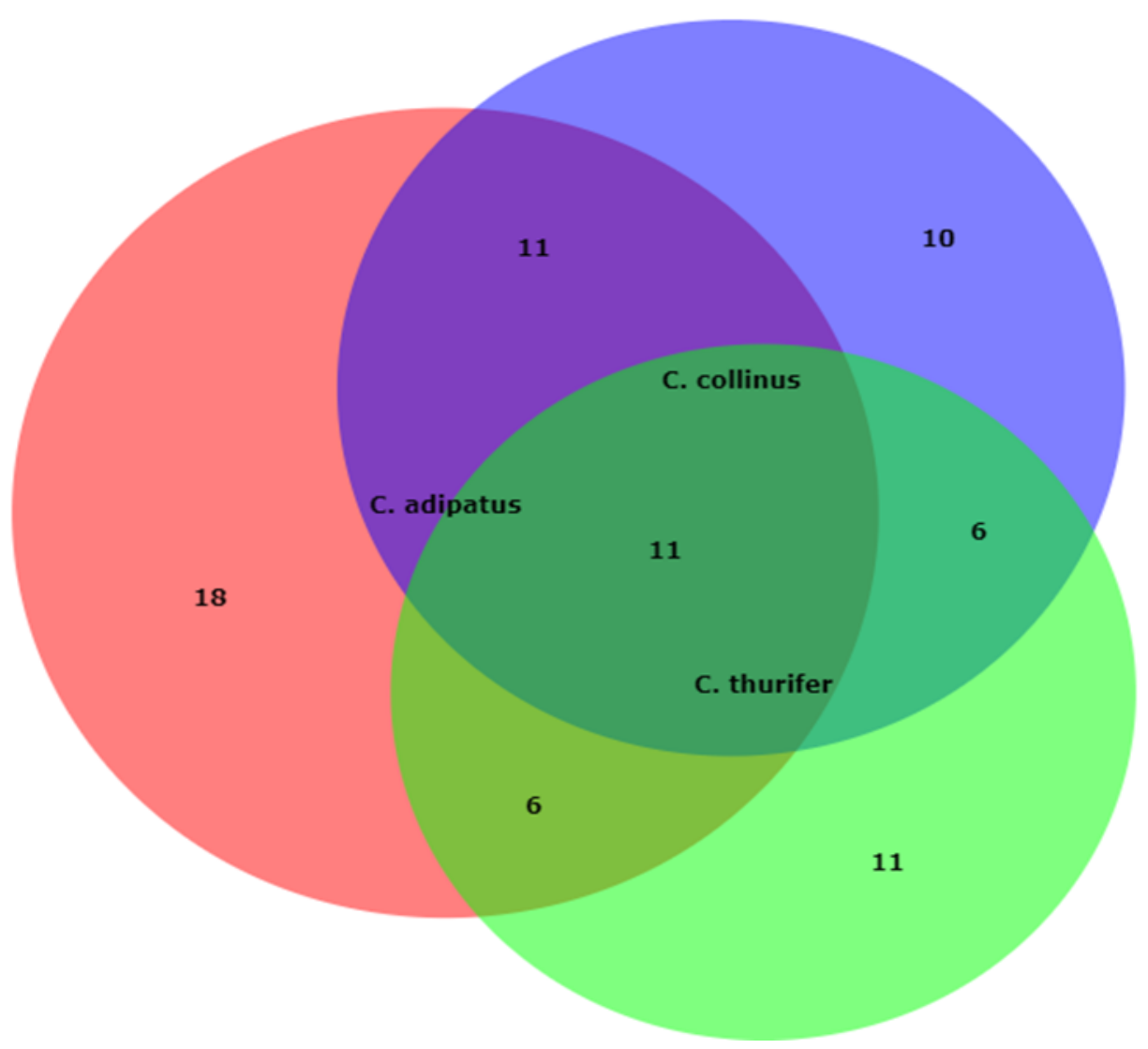

Figure 1. Venn diagram showing both the number of compounds shared and unshared/peculiar among the three Croton essential oils.

\subsection{Antimicrobial Activity of the Essential Oils of Croton Species}

\subsubsection{Agar Diffusion Method}

Table 2 shows that $C$. adipatus essential oil at a concentration of $50 \%$ inhibited the growth of $S$ aureus $(20.0 \pm 0 \mathrm{~mm}$ ), while a concentration of $95 \%$ inhibited the growth of B. subtilis $(25.0 \pm 0 \mathrm{~mm})$ and E. coli $(20.03 \pm 0.29 \mathrm{~mm})$, while at $10 \%$ inhibited C. albicans $(19.67 \pm 1.47 \mathrm{~mm})$. On the other hand, no significant activity was observed against P. aeruginosa. Additionally, C. thurifer (concentration 10\%, 50\% and 95\%) essential oil presented inhibition halos ranging from 11 to $14 \mathrm{~mm}$ for S. aureus, B. subtilis, E. coli, and P. aeruginosa. In C. albicans was observed an inhibition halo of $15.03 \pm 0.38 \mathrm{~mm}$ at $10 \%$. C. collinus (concentration 10\%,50\% and 95\%) presented inhibition halos between 11 and $15 \mathrm{~mm}$ for S. aureus, B. subtilis, E. coli, and C. albicans (Table 2 and Figure 2). 
Table 2. Comparative table of the antimicrobial activity of essential oils and standards by the agar diffusion method.

\begin{tabular}{|c|c|c|c|c|c|c|c|c|c|c|c|}
\hline \multirow{4}{*}{ Microorganism } & \multicolumn{11}{|c|}{ Zone of Inhibition (mm) } \\
\hline & \multicolumn{9}{|c|}{ Essential Oil } & \multicolumn{2}{|c|}{ Positive Control } \\
\hline & \multicolumn{3}{|c|}{ Croton adipatus } & \multicolumn{3}{|c|}{ Croton thurifer } & \multicolumn{3}{|c|}{ Croton collinus } & \multirow{2}{*}{$\begin{array}{c}\text { CIP } \\
{[0.05} \\
\mathrm{mg} / \mathrm{mL}]\end{array}$} & \multirow{2}{*}{$\begin{array}{c}\text { KET } \\
{[0.2} \\
\mathrm{mg} / \mathrm{mL}]\end{array}$} \\
\hline & $10 \%$ & $50 \%$ & $95 \%$ & $10 \%$ & $50 \%$ & $95 \%$ & $10 \%$ & $50 \%$ & $95 \%$ & & \\
\hline Sa & $\begin{array}{c}13.13 \pm \\
0.44^{*}\end{array}$ & $20 \pm 0 *$ & $14.2 \pm 0.7$ & $\begin{array}{c}11.47 \pm \\
0.5^{*}\end{array}$ & $12 \pm 0 *$ & $\begin{array}{c}14.07 \pm \\
0.41^{*}\end{array}$ & $\begin{array}{c}10.53 \pm \\
0.55 *\end{array}$ & $\begin{array}{c}11.03 \pm \\
0.52 *\end{array}$ & $12 \pm 0$ * & $39 \pm 0$ & n.d. \\
\hline Bs & $\begin{array}{c}13.1 \pm \\
1.32 *\end{array}$ & $\begin{array}{c}17.13 \pm \\
0.34^{*}\end{array}$ & $25 \pm 0 *$ & $11.5 \pm 0$ * & $\begin{array}{c}12.53 \pm \\
0.46^{*}\end{array}$ & $\begin{array}{c}12.17 \pm \\
1.25^{*}\end{array}$ & $\begin{array}{c}12.6 \pm 0.8 \\
*\end{array}$ & $\begin{array}{c}14.53 \pm \\
0.4^{*}\end{array}$ & $15 \pm 0$ * & $\begin{array}{c}52.3 \pm \\
1.1\end{array}$ & n.d. \\
\hline Ec & $\begin{array}{c}14.03 \pm \\
0.41\end{array}$ & $16 \pm 0$ & $\begin{array}{c}20.03 \pm \\
0.29^{*}\end{array}$ & $10 \pm 0$ * & $\begin{array}{c}12.03 \pm \\
0.48^{*}\end{array}$ & $\begin{array}{c}11.53 \pm \\
0.5^{*}\end{array}$ & $11 \pm 0$ * & $\begin{array}{c}11.57 \pm \\
0.5^{*}\end{array}$ & $\begin{array}{c}10.6 \pm \\
1.63^{*}\end{array}$ & $15 \pm 0$ & n.d. \\
\hline $\mathrm{Pa}$ & $\begin{array}{c}11.27 \pm \\
1.02 *\end{array}$ & $\begin{array}{c}11.53 \pm \\
0.5^{*}\end{array}$ & $\begin{array}{c}13.57 \pm \\
0.85^{*}\end{array}$ & $10 \pm 0 *$ & $12.5 \pm 0$ * & $11 \pm 0$ * & $\begin{array}{c}11.63 \pm \\
1.31^{*}\end{array}$ & $\begin{array}{c}12.7 \pm \\
0.79 *\end{array}$ & $\begin{array}{c}11.03 \pm \\
0.52 \text { * }\end{array}$ & $34 \pm 0$ & n.d. \\
\hline $\mathrm{Ca}$ & $\begin{array}{c}19.67 \pm \\
1.47^{\#}\end{array}$ & $12.5 \pm 0^{\#}$ & $11 \pm 0^{\#}$ & $\begin{array}{c}15.03 \pm \\
0.38^{\#}\end{array}$ & $11 \pm 0^{\#}$ & $10 \pm 0$ \# & $15 \pm 0$ \# & $\begin{array}{c}10.53 \pm \\
0.55^{\#}\end{array}$ & $10 \pm 0^{\#}$ & n.d. & $35 \pm 0$ \\
\hline
\end{tabular}

CIP: Ciprofloxacin; KET: ketoconazole; Sa: S. aureus; Bs: B. subtilis; Ec: E. coli; Pa: P. aeruginosa; Ca: C. albicans; n.d.: non-determined. ${ }^{*} P<0.05$; Test Dunnet, mean values were compared to Ciprofloxacin group. ${ }^{\#} P<0.05$; Test Dunnet, mean values were compared to Ketoconazole group.

In other studies of the Croton genus regarding the antimicrobial activity (diffusion method, the following inhibition halos were reported:

In S. aureus: C. borarium leaves at 100\% (22.5 mm) [16] and C. gratissimus leaves at $5 \mathrm{mg} / \mathrm{mL}(21.6 \mathrm{~mm})$ [39]. Similar results were obtained in our study of C. adipatus at 50\% $(20.0 \mathrm{~mm})$. On the other hand, other authors reported that the essential oils of the following plant species did not have good activity: leaves and stems of C. zehntneri at $50 \mu \mathrm{g} /$ disc $(14.53 \pm 0.25 \mathrm{~mm})$ [36] in C. geayi leaves at 100\% (10 mm) and C. greveanus leaves at $100 \%$ $(11.5 \mathrm{~mm})$ [16]; as well as in C. thurifer at $95 \%(14.07 \mathrm{~mm})$ and C. collinus at $95 \%(12 \mathrm{~mm})$ (Table 2 and Figure 2).

Regarding B. subtilis; the essential oils of C. zehntneri at $5 \mu \mathrm{g} / \mathrm{disc}$ and $25 \mu \mathrm{g} / \mathrm{disc}$ ( $<8 \mathrm{~mm}$ and $13.33 \pm 0.42 \mathrm{~mm}$, respectively) [36], C. borarium (15 mm), C. geayi ( $9 \mathrm{~mm})$, and C. greveanus leaves $(13.2 \mathrm{~mm})$ at $100 \%$ [16] did not have a significant activity against this strain. Similar results were evidenced in C. thurifer at 50\% (12.53 mm) and C. collinus at 95\% (15 mm). However, C. adipatus at 95\% showed an inhibition halo of $25.0 \mathrm{~mm}$ (Table 2 and Figure 2).

For E. coli, the essential oil from C. gratissimus leaves at $5 \mathrm{mg} / \mathrm{mL}$ reported an inhibition halo of $23.0 \mathrm{~mm}$ [39], similar results were obtained with C. adipatus at 95\% (20.03 mm). On the other hand, other studies reported that the essential oils of the following plant species did not have good activity: C. zehntneri leaves and stems [36], C. hieronymi roots and leaves [24], C. borarium, C. geayi, and C. greveanus leaves [16]; similar results were observed in C. thurifer at 50\% (12.03 $\mathrm{mm})$ and C. collinus at 50\% (12.7 $\mathrm{mm})$ (Table 2 and Figure 2).

In P. aeruginosa, C. borarium leaves at $100 \%$ showed an inhibition halo of $18.3 \mathrm{~mm}$ [16]. In contrast, C. zehntneri at 5, 25, and $50 \mathrm{ug} /$ disc $(<8 \mathrm{~mm})$ [36], C. geayi leaves at $100 \%$ (3.17 mm), C. greveanus leaves at 100\% (8.01 mm) [16], and C. gratissimus leaves at $5 \mathrm{mg} / \mathrm{mL}$ $(11.0 \pm 0.6 \mathrm{~mm})[39]$ did not show antimicrobial activity being similar with our findings, which ranges between $10 \pm 0 \mathrm{~mm}$ and $13.57 \pm 0.85 \mathrm{~mm}$ (Table 2 and Figure 2).

For C. albicans, the following Croton species did not have a significant activity such as C. zehntneri leaves and stems at $5 \mathrm{ug} / \operatorname{disc}(<8 \mathrm{~mm})$ and $25 \mathrm{ug} / \operatorname{disc}(<8 \mathrm{~mm})$ [36], C. hieronymi roots and leaves at $1000 \mu \mathrm{g} / \mathrm{mL}$ (7.9 and $0 \mathrm{~mm}$, respectively) [24], and C. cajucara at $100 \%$ had ranging from $6-10 \mathrm{~mm}$ [18]. Similar results were obtained for $C$. thurifer and $C$. collinus with inhibition zones between 10 and $15 \mathrm{~mm}$. Otherwise, in the present study, $C$. adipatus at $10 \%$ reported an inhibition halo of $19.67 \mathrm{~mm}$ (Table 2 and Figure 2). 


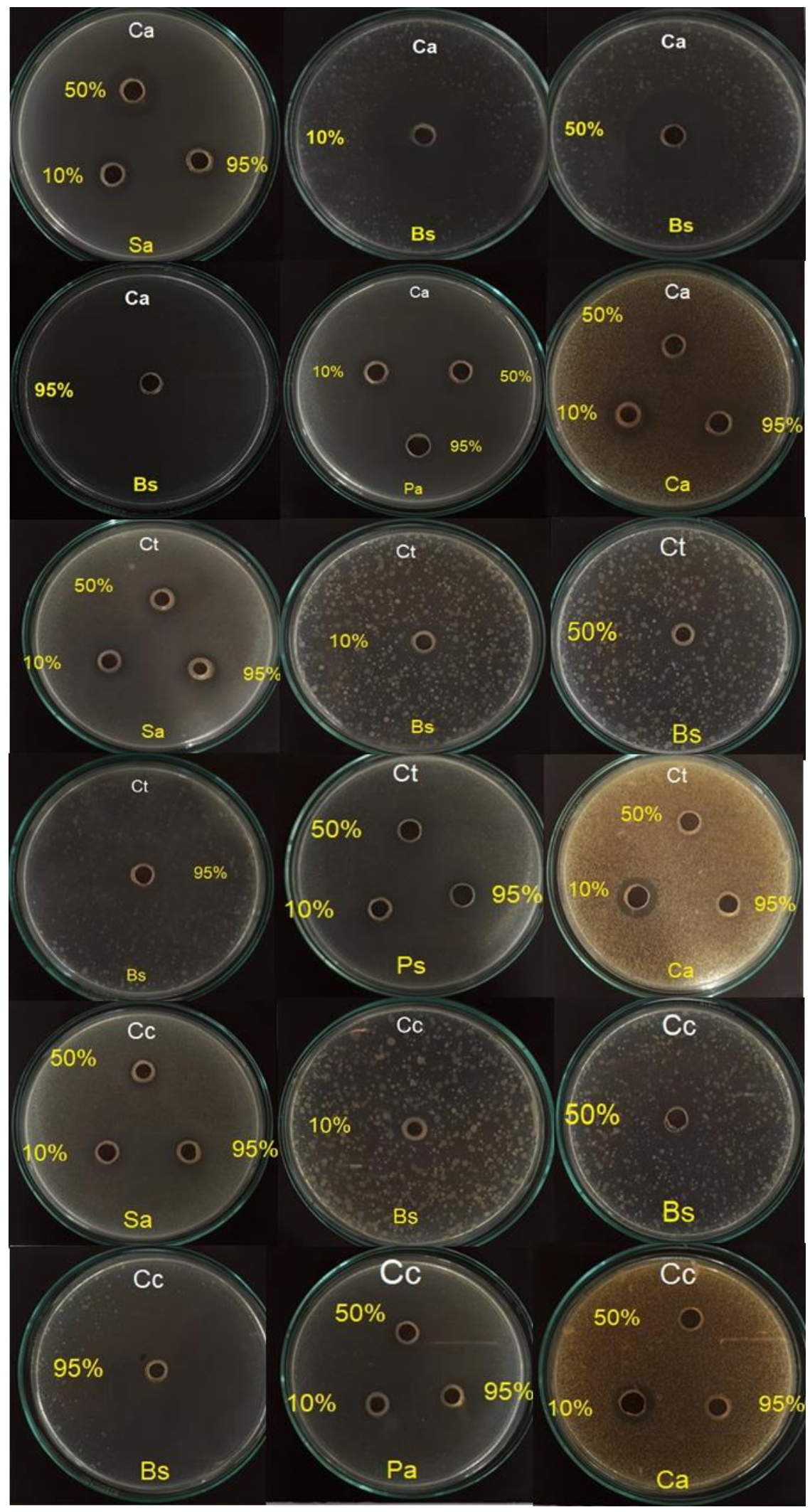

Figure 2. Antimicrobial activity of Croton species at different concentrations $10 \%, 50 \%$ and $95 \%$ by the agar diffusion method. The white acronym represents the analyzed plant species: Ca (C. adipatus); $\mathrm{Ct}$ (C. thurifer), Cc (C. collinus); while the yellow acronym represents microorganisms such as Sa (S. aureus), Bs (B. subtilis), $\mathrm{Pa}$ (P. aeruginosa), and Ca (C. albicans); the yellow letters represent the concentration percentages of each essential oil. 
Results for this type of preliminary antimicrobial test showed a certain degree of variability, which could be explained by different factors that influence the solubility of the essential oils in the medium to be diffused, the polarity of the essential oil, and the molecular size of the components that comprise the essential oil, among others; therefore, they would not necessarily correlate with the results of other specific tests such as microdilution or dilution in broth. Regarding the biochemical mechanisms involved in the antimicrobial activity of essential oils, some compounds like p-cymene at $2500 \mu \mathrm{g} / \mathrm{mL}$ have shown alterations in the membrane potential of $S$. aureus, and also $\gamma$-terpinene at 2500 and $3400 \mu \mathrm{g} / \mathrm{mL}$ [40]. $\beta$-caryophyllene, the major component in C. collinus was able to alter membrane permeability and integrity of B. cereus, leading possibly to cell death [41]. This finding is related to our results against $B$. subtilis, which only was selective for this strain (Tables 2 and 3). Limonene, the third abundant component in C. adipatus, is linked to the respiratory metabolism of $S$. aureus [42]. Otherwise, terpenes are also related to disorders of mitochondrial membrane in Candida species but with low antifungal activity. Moreover, oxygenated sesquiterpenes demonstrated a negative effect on Saccharomyces and Candida strains such as caryophyllene oxide, humulene epoxide, spathulenol, and $\alpha$-Muurolol in high concentrations [43].

Table 3. Comparative table of the minimum inhibitory concentration (MIC) of the essential oils and standards by the colorimetric microdilution method.

\begin{tabular}{|c|c|c|c|c|c|}
\hline \multirow{3}{*}{ Microorganism } & \multicolumn{5}{|c|}{ Minimum Inhibitory Concentration (MIC) } \\
\hline & \multicolumn{3}{|c|}{ Essential Oil $(\mu \mathrm{g} / \mathrm{mL})$} & \multicolumn{2}{|c|}{ Positive Control $(\mu \mathrm{g} / \mathrm{mL})$} \\
\hline & Croton adipatus & Croton thurifer & Croton collinus & Ciprofloxacin & Ketoconazole \\
\hline Sa & $>1000$ & $296.1 \pm 0$ & $>1000$ & $0.5 \pm 0$ & n.d. \\
\hline Bs & $286.4 \pm 0$ & $148 \pm 0$ & $72 \pm 0$ & $0.13 \pm 0$ & n.d. \\
\hline Ec & $>1000$ & $>1000$ & $>1000$ & $4 \pm 0$ & n.d. \\
\hline $\mathrm{Pa}$ & $>1000$ & $>1000$ & $>1000$ & $32 \pm 0$ & n.d. \\
\hline $\mathrm{Ca}$ & $572.8 \pm 0$ & $>1000$ & $576.2 \pm 0$ & n.d. & $0.03 \pm 0$ \\
\hline
\end{tabular}

Sa: S. aureus; Bs: B. subtilis; Ec: E. coli; Pa: P. aeruginosa; Ca: C. albicans; n.d.: non-determined.

\subsubsection{Colorimetric Microdilution Method}

According to our results showed in Table 3 and Figure 3, the essential oil of $C$. adipatus showed antimicrobial activity against B. subtilis (MIC $=286.4 \mu \mathrm{g} / \mathrm{mL}$ ) and $C$. albicans (MIC $=572.8 \mu \mathrm{g} / \mathrm{mL}$ ) and did not show activity against $S$. aureus ATCC 25923 $(\mathrm{MIC}>1000 \mu \mathrm{g} / \mathrm{mL})$, E.coli $(\mathrm{MIC}=1000 \mu \mathrm{g} / \mathrm{mL}$ ) and P. aeruginosa $(\mathrm{MIC}>1000 \mu \mathrm{g} / \mathrm{mL}$ ). The essential oil of $C$. thurifer showed activity against the following bacteria: $S$. aureus $(\mathrm{MIC}=296.1 \mu \mathrm{g} / \mathrm{mL})$ and B. subtilis $(\mathrm{MIC}=148 \mu \mathrm{g} / \mathrm{mL})$. Furthermore, it did not show activity against $E$. coli (MIC $>1000 \mu \mathrm{g} / \mathrm{mL}$ ), P. aeruginosa (MIC $>1000 \mu \mathrm{g} / \mathrm{mL}$ ), and C. albicans (MIC $=>1000 \mu \mathrm{g} / \mathrm{mL}$ ). The essential oil of $C$. collinus showed antimicrobial activity against B. subtilis (MIC $=72 \mu \mathrm{g} / \mathrm{mL}$ ), and C. albicans (MIC $=576.2 \mu \mathrm{g} / \mathrm{mL}$ ). Additionally, it did not show activity against $S$. aureus (MIC $>1000 \mu \mathrm{g} / \mathrm{mL}$ ), E. coli (MIC $>1000 \mu \mathrm{g} / \mathrm{mL}$ ), and $P$. aeruginosa (MIC $>1000 \mu \mathrm{g} / \mathrm{mL}$ ) (Table 3 and Figure 3).

In $S$. aureus, good activity was evidenced in the aerial parts of $C$. zambesicus $(\mathrm{MIC}=16 \mu \mathrm{g} / \mathrm{mL})$ [17]. C. cajucara leaves $(\mathrm{MIC}=33.4 \mu \mathrm{g} / \mathrm{mL})$ [18], C. campestris $(\mathrm{MIC}=128 \mu \mathrm{g} / \mathrm{mL})$ [32], C. zehntneri stems and leaves $(\mathrm{MIC}=145.0 \mu \mathrm{g} / \mathrm{mL})$ [36], in the aerial parts of $C$. heliotropiifolius ( $\mathrm{MIC}=500 \mu \mathrm{g} / \mathrm{mL}$ ) [44], C. limae leaves $(\mathrm{MIC}=512 \mu \mathrm{g} / \mathrm{mL})$ [45], and C. gratissimus leaves $(\mathrm{MIC}=600 \mu \mathrm{g} / \mathrm{mL})$ [39]. Similar results were obtained in the present study for $C$. thurifer leaves (MIC $=296.1 \mu \mathrm{g} / \mathrm{mL}$ ). On the other hand, other investigations reported that the essential oils of the following plant species did not have a good activity such as C. borarium (MIC $=1151 \mu \mathrm{g} / \mathrm{mL}$ ) [16], C. greveanus $(\mathrm{MIC}=1126 \mu \mathrm{g} / \mathrm{mL})[16]$, and C. geayi $(\mathrm{MIC}=2260 \mu \mathrm{g} / \mathrm{mL})$ [16]. 


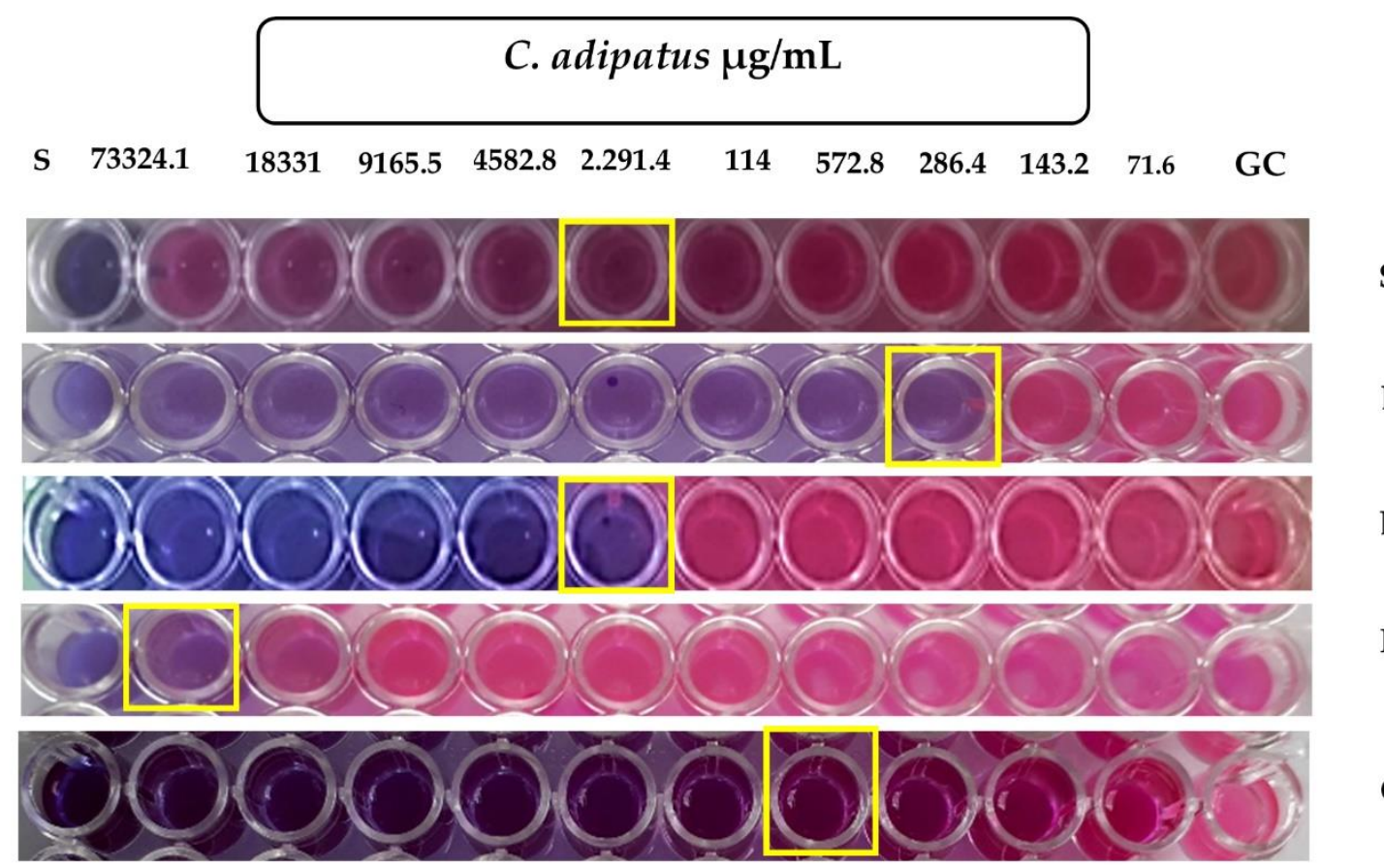

Sa

Bs

Ec

Pa

$\mathrm{Ca}$

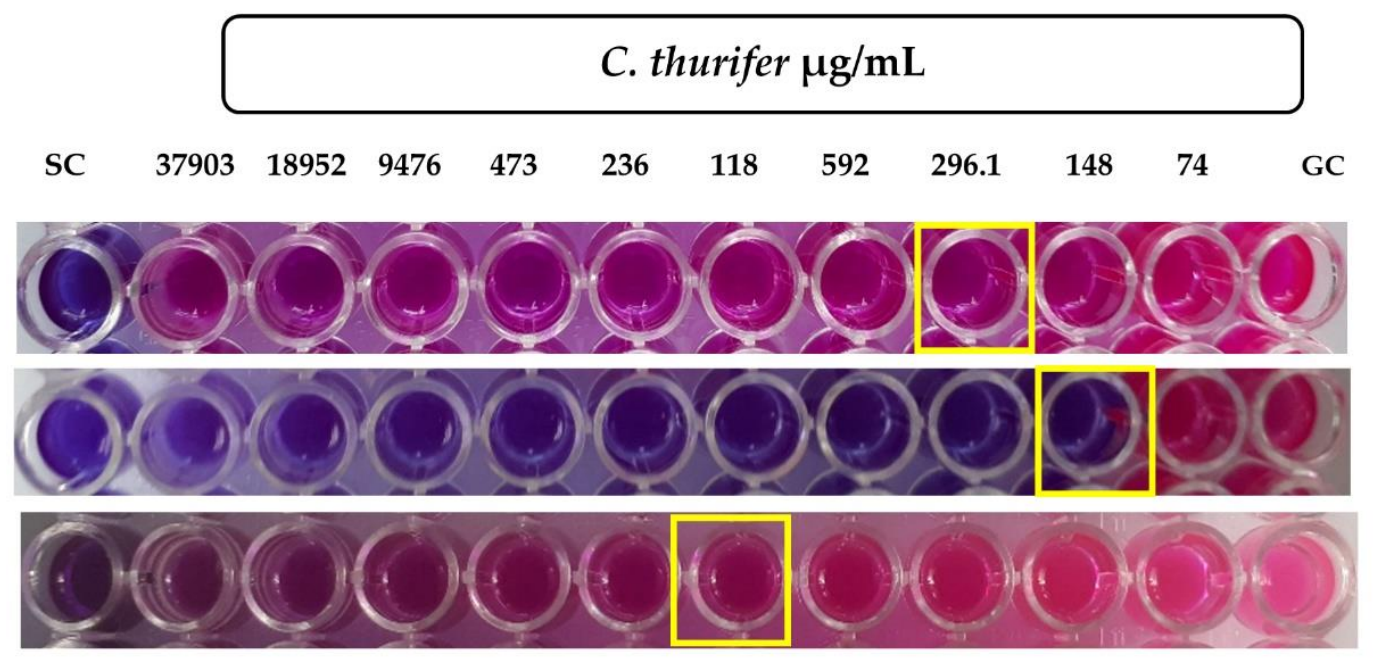

Sa

Bs

$\mathrm{Ca}$

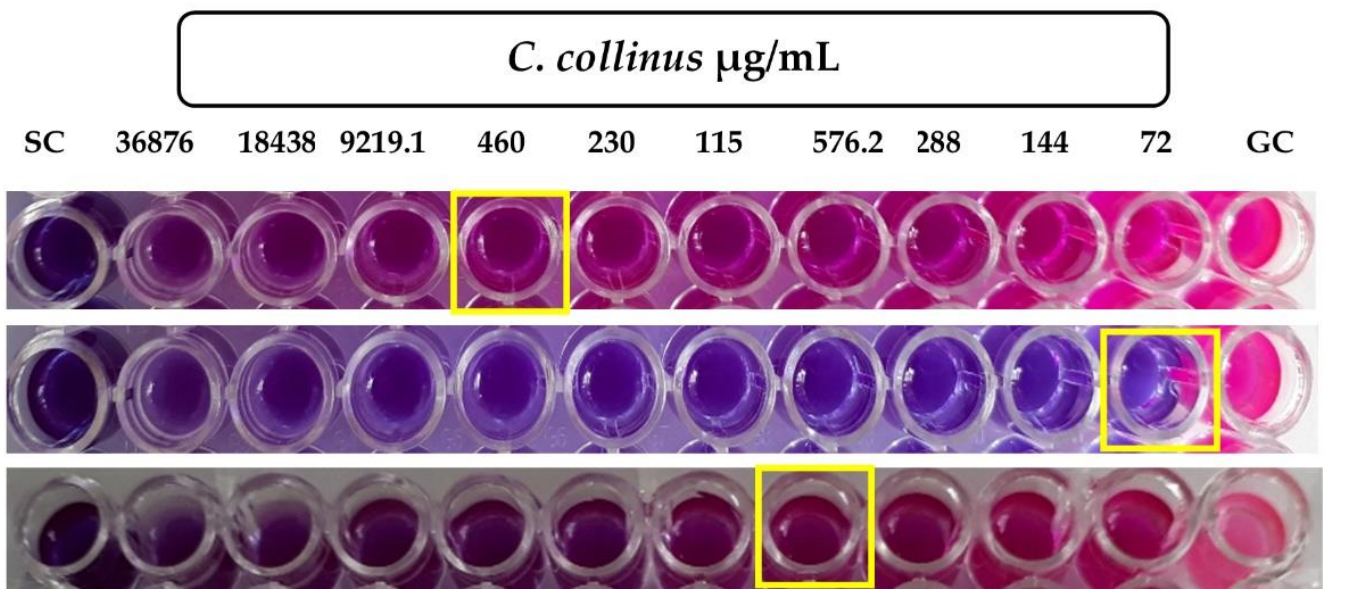

Sa

Bs

Ca

Figure 3. Determination of the minimum inhibitory concentration of the essential oil and standard drugs. SC (Sterility Control), GC (Growth Control), Sa (S. aureus), Bs (B. subtilis), Ec (E. coli), Pa (P. aeruginosa), Ca (C. albicans).

In B. subtilis, other Croton species presented good activity such as: C. zambesicus steam and leaves (MIC $=16 \mu \mathrm{g} / \mathrm{mL}$ ) [17], C. heliotropiifolius aerial parts (MIC $=62.5 \mu \mathrm{g} / \mathrm{mL})$ [44], C. zehnt- 
neri steam and leaves $(\mathrm{MIC}=58.75 \mu \mathrm{g} / \mathrm{mL})$ [36], and C. borarium leaves $(\mathrm{MIC}=287 \mu \mathrm{g} / \mathrm{mL})$ [16]. Similar results were obtained for the essential oils of the leaves of the three species of Croton, obtaining better results for $C$. collinus (MIC $=72 \mu \mathrm{g} / \mathrm{mL}$ ), followed by C. thurifer $(\mathrm{MIC}=148 \mu \mathrm{g} / \mathrm{mL})$, and C. adipatus $(\mathrm{MIC}=286.4 \mu \mathrm{g} / \mathrm{mL})$. On the other hand, $\mathrm{C}$. greveanus leaves $(\mathrm{MIC}=1126 \mu \mathrm{g} / \mathrm{mL})$ [16], and C. geayi $(\mathrm{MIC}=4520 \mu \mathrm{g} / \mathrm{mL})$ [16] did not present activity against this microorganism.

For E. coli, the following authors reported a significant activity in C. zambesicus stems and leaves (MIC $=16 \mu \mathrm{g} / \mathrm{mL})$ [17] and C. hieronymi $(\mathrm{MIC}=100 \mu \mathrm{g} / \mathrm{mL})$ [24]. On the other hand, C. limae leaves (MIC $\geq 1024 \mu \mathrm{g} / \mathrm{mL}$ ) [45], C. boraium leaves (MIC $=1151 \mu \mathrm{g} / \mathrm{mL})$ [45], C. greveanus $(\mathrm{MIC}=4505 \mu \mathrm{g} / \mathrm{mL})$ [16], and C. gratissimus leaves $(\mathrm{MIC}=1300 \mu \mathrm{g} / \mathrm{mL})$ [16]. Similarly, in our study, no activity was found in C. adipatus, C. thurifer and C. collinus.

In P. aeruginosa, C. zambesicus leaves showed an inhibition at $250 \mu \mathrm{g} / \mathrm{mL}$ [17]. Meanwhile C. limae leaves $(\mathrm{MIC}=1024 \mu \mathrm{g} / \mathrm{mL})$ [17], C. boraium leaves $(\mathrm{MIC}=1151 \mu \mathrm{g} / \mathrm{mL})$ [16], C. greveanus (MIC $=4505 \mu \mathrm{g} / \mathrm{mL})$ [16], and C. gratissimus leaves (MIC=5000 $\mu \mathrm{g} / \mathrm{mL})$ [39] did not show promising results, as well as the studied species of Croton in our study.

For C. albicans, a good activity was reported according to Alviano et al. in C. cajucara leaves $(\mathrm{MIC}=13.4 \mu \mathrm{g} / \mathrm{mL})$ [18], C. zehntneri stem and leaves $(\mathrm{MIC}=58.75 \mu \mathrm{g} / \mathrm{mL})$ [36], and in C. hieronymi roots (MIC $=100 \mu \mathrm{g} / \mathrm{mL}$ ) [24]. Similar results were presented in the present study for the species of C. adipatus ( $\mathrm{MIC}=571 \mu \mathrm{g} / \mathrm{mL})$ and C. collinus $(\mathrm{MIC}=574 \mu \mathrm{g} / \mathrm{mL})$. On the other hand, C. hieronymi roots (MIC $>1000 \mu \mathrm{g} / \mathrm{mL}$ ) [24] did not present activity, in the same way with $C$. thurifer (MIC $>1000 \mu \mathrm{g} / \mathrm{mL}$ ). MIC of standard drugs are shown in Table 3 and in Supplementary Materials Figure S7.

As is evidenced in the present study, the species of $C$. adipatus, C. thurifer, and C. collinus showed antimicrobial activity according to the microdilution test against Gram-positive and yeast. Other studies of the Croton species revealed diverse activity on the microorganisms under study, which means the high variability of the components present and associated with this activity. Various studies mention a slight sensitivity of Gram positive compared to Gram-negative. The main reason is the presence of the extracellular membrane in Gramnegative microorganisms, which regulate the passage of hydrophobic components and thus prevents the alteration of the membrane's permeability [46]. Likewise, various studies attribute the antimicrobial activity in essential oils to the following components: terpinen4-ol [4], $\alpha$-terpinene [47], 1,8-cineole [48], $\delta$-cadinene, $\gamma$-muurolene, $\alpha$-muurolene [49], $\beta$-caryophyllene [50], $\beta$-elemene [51], germacrene [52], p-cymene [53], $\gamma$-terpinene [54], $\beta$ myrcene [55], $\alpha$-pinene [56], $\beta$-pinene [56], linalool [57], $\alpha$-phellandrene [58], among others. All these components were found in the essential oils of Croton in our study. Furthermore, the observed activity could also be explained by the presence of the components in higher proportion or by the synergistic action between them.

Based on our results, we might suppose that the three essential oils had a selective effect against a specific bacterium and on C. albicans. Each metabolite determined could be acting by different mechanisms and according to our chemical analysis, each Croton species showed a different phytochemical marker, which contributes to the antimicrobial activity. Hydrocarbon monoterpenes were the most abundant chemical groups in C. adipatus. However, in $C$. thurifer and C. collinus were the sesquiterpenes, which might be linked to this difference in the results showed in Table 2 and Table Therefore, the volatile chemicals would be responsible for the antimicrobial effect on S. aureus, B. subtilis, and C. albicans, and not the major phytochemical determined in the GC-MS analysis. Some studies reported that terpenes do not constitute a high inherent antimicrobial effect i.e., some terpenes like p-cymene, the major compound in thyme, had no effect against several Gram-negative bacteria. Also, other chemicals, which were found in Croton essential oils such as $\alpha$-pinene, limonene, $\delta$-3-carene, sabinene, $\alpha$-pinene, $\beta$-pinene, and $\alpha$-terpinene revealed no or low effect against different pathogen bacteria, whether Gram-negative or Gram-positive. Additionally, $\alpha$-pinene, $\beta$-pinene, p-cymene, $\beta$-myrcene, $\beta$-caryophyllene, limonene, and $\gamma$-terpinene had low or absent activity against Escherichia coli, Staphylococcus aureus, and Bacillus cereus and p-cymene and $\gamma$-terpinene were ineffective against Saccha- 
romyces cerevisiae [40]. Thus, these reports in vitro indicate that single terpene compounds are inefficient as antimicrobials, which supports our study to understand the relationship between the chemical composition of each Croton species with antimicrobial activity.

\section{Materials and Methods}

\subsection{Collection of the Plant Material}

Croton adipatus Kunth and Croton thurifer Kunth were collected in the locality El Almendral in the district of Jaen of the province of Jaen, Departament of Cajamarca, at an altitude of 650 meters above sea level, and Croton collinus Kunth was collected in Jahuanga, district of Bagua Grande in the province of Utcubamba of the department of Amazonas, at an altitude of 700 meters above sea level, in June 2017 during the dry season. Leaves were separated, selected and dried in open air, avoiding exposure to direct sunlight in order to preserve the volatile components and also to achieve a longer storage time. The identification and taxonomic classification of plant species were developed by the botanical consultant José Campos de la Cruz.

\subsection{Extraction of Essential Oils of Croton Species}

The extraction was developed by hydrodistillation using a Clevenger apparatus for two hours. Milligrams of anhydrous sulfate were added to remove residual water. Then it was stored at $4^{\circ} \mathrm{C}$ until further use [59]. The following formula was used to calculate the yield percentage:

$$
\text { Yield percentage }(\%)=\frac{\text { volume of EO in } m L}{\text { Weight of EO in } g} \times 100
$$

where EO: essential oil.

3.3. Chemical Analysis by Gas Chromatography Coupled to Mass Spectrometry (GC-MS) of the Essential Oils of Croton Species

For the analysis of each Croton species, $20 \mu \mathrm{L}$ of the essential oil was used in $980 \mu \mathrm{L}$ of dichloromethane, which were injected into the Agilent Technologies 7890A gas chromatograph coupled to an Agilent Technologies 5975C mass selective detector. The separation of the compounds from the mixture was carried out using a DB-5MS apolar capillary column $(60 \mathrm{~m} \times 250 \mu \mathrm{m} \times 0.25 \mu \mathrm{m})(\mathrm{J} \& \mathrm{~W}$ of $5 \%$ phenyl methylpolysiloxane). The injector temperature was kept at $250{ }^{\circ} \mathrm{C}$ and the injection was carried out in split mode (20: 1). The oven temperature program was as follows: initial temperature $50^{\circ} \mathrm{C}$; subsequently, it was increased to $2.5^{\circ} \mathrm{C} / \mathrm{min}$ up to $180{ }^{\circ} \mathrm{C}, 10^{\circ} \mathrm{C} / \mathrm{min}$ up to $200^{\circ} \mathrm{C}$, and finally at $20^{\circ} \mathrm{C} / \mathrm{min}$ up to $240^{\circ} \mathrm{C}$. The run time was of $56 \mathrm{~min}$, using helium as a stripping gas at a constant flow of $1 \mathrm{~mL} / \mathrm{min}$. The constituents of essential oils were identified by comparing the mass spectra of each peak with those of the mass spectra library of the Flavor 2 databases and that of the National Institute of Standards and Technology (NIST, 08). This analysis was carried out in the laboratory of the Natural Products Research Unit of the Faculty of Sciences and Philosophy "Alberto Cazorla Talleri", Universidad Peruana Cayetano Heredia.

\subsection{Evaluation of the Antimicrobial Activity of the Essential Oils of Croton Species}

\subsubsection{Agar Diffusion Method}

The antibacterial activity of C. adipatus, C. thurifer, and C. collinus essential oils were tested against the following species: Staphylococcus aureus ATCC 25923, Bacillus subtilis ATCC 6633, Escherichia coli ATCC 25922, Pseudomonas aeruginosa ATCC 9027 and the yeast Candida albicans ATCC Bacteria and yeast were sub-cultured on Trypticase Soy agar and Dextrose Sabouraud agar, respectively, $24 \mathrm{~h}$ before the test. The suspension of the microorganisms was prepared in sterile $0.9 \%$ saline solution, and the turbidity was adjusted according to the 0.5 tube of the McFarland scale, which corresponds to an approximate concentration of $1-2 \times 10^{8} \mathrm{CFU} / \mathrm{mL}$ for bacteria and $1-5 \times 10^{6} \mathrm{CFU} / \mathrm{mL}$ for yeast. 
Petri dishes were prepared as follows: Müeller Hinton agar was used for bacteria and Sabouraud Dextrose agar for yeast, previously reconstituted with distilled water, sterilized by autoclaving, cooled and kept between $45^{\circ} \mathrm{C}$ and $50{ }^{\circ} \mathrm{C}$. These were inoculated with $0.4 \mathrm{~mL}$ of inoculum suspension for every $100 \mathrm{~mL}$ of culture medium, then it was homogenized and distributed in sterile glass Petri dishes of $90 \mathrm{~mm}$ in diameter, at a rate of $25 \mathrm{~mL}$ per plate. It was allowed to solidify, and wells were made using a sterile corkborer. Then, $100 \mu \mathrm{L}$ of the concentrations of the essential oils $(10 \%, 50 \%$, and $95 \%)$ were incorporated in each well, and finally were kept for $30 \mathrm{~min}$ under refrigeration to enhance the diffusion of the essential oils and to avoid the proliferation of microorganisms, then it was incubated in an oven at $37^{\circ} \mathrm{C}$ for $24 \mathrm{~h}$. Ciprofloxacin $(0.05 \mathrm{mg} / \mathrm{mL})$ and Ketoconazole $(0.2 \mathrm{mg} / \mathrm{mL})$ dissolved in water and dimethylsulfoxide (DMSO), respectively, were used as positive controls. Solvent controls (DMSO) were included in each experiment as negative controls. Tests were carried out in triplicate. After incubation, the presence of growth inhibition zones was observed, and the diameters were measured in $\mathrm{mm}$. It was considered a significant antimicrobial activity to a perfectly clear area with a diameter greater than $18 \mathrm{~mm}[60]$.

\subsubsection{Colorimetric Microdilution Method and Determination of MIC}

The antibacterial activity was performed by colorimetric microdilution method utilizing 96-well microtiter plates to determine the minimum inhibitory concentration (MIC). The following microorganisms were used: Staphylococcus aureus ATCC 25923, Bacillus subtilis ATCC 6633, Escherichia coli ATCC 25922, Pseudomonas aeruginosa ATCC 9027, and Candida albicans ATCC The microorganisms were kept for $24 \mathrm{~h}$ before the test on Trypticase Soya agar for bacteria and Dextrose Sabouraud agar for yeast and incubated at aerobic conditions at $37^{\circ} \mathrm{C}$. Later, a few colonies of the microorganisms in sterile $0.9 \%$ saline solution was prepared with the help of a Kolle handle and the turbidity of the bacterial suspension was adjusted according to the 0.5 tube of the McFarland scale, which corresponds to an approximate concentration of 1-2 $10^{8} \mathrm{CFU} / \mathrm{mL}$ for bacteria and 1-5 $\times 10^{6} \mathrm{CFU} / \mathrm{mL}$ for yeasts. In bacteria, dilutions were made with Müeller Hinton broth to obtain an inoculum of $6.6-13.3 \times 10^{5} \mathrm{CFU} / \mathrm{mL}(2 \mathrm{x}$ inoculum). For yeast, consecutive dilutions were made with RPMI 1640 medium to obtain an inoculum of $1-5 \times 10^{3} \mathrm{CFU} / \mathrm{mL}$ ( $2 \mathrm{X}$ inoculum). For each $20 \mathrm{~mL}$ of the suspensions of the $2 \mathrm{x}$ inocula (bacteria or yeast), $0.1 \mathrm{~mL}$ of $20 \mathrm{mg} / \mathrm{mL}$ resazurin solution was added, which was previously prepared under aseptic conditions using a $0.22 \mu \mathrm{m}$ filter. The stock solutions of the essential oils were prepared at a concentration of $800 \mu \mathrm{L} / \mathrm{mL}$ [essential oil (80): polysorbate 20 (50): Müeller Hinton broth (870)], for testing in bacteria and yeast. The final concentrations $(x)$ of the samples ranged from 0.079 to $40 \mu \mathrm{L} / \mathrm{mL}$. The positive controls used for the tests were Ciprofloxacin and Ketoconazole, following the CLSI recommendations [61]. The final concentrations $(\mathrm{x})$ of the controls ranging from 0.125 to $64 \mu \mathrm{g} / \mathrm{mL}$ and from 0.0313 to $16 \mu \mathrm{g} / \mathrm{mL}$ for Ciprofloxacin and Ketoconazole respectively. The Müeller Hinton broth with resazurin was used as a sterility control in the case of Ciprofloxacin and the RPMI 1640 medium with resazurin according to the protocol of Liu M et al. [62] in Ketoconazole. $100 \mu \mathrm{L}$ (essential oil or positive control) of the $2 x$ inoculum was mixed with resazurin indicator. On the other hand, sterility control wells contained Müeller Hinton broth or RPMI 1640 medium, containing resazurin and growth control wells had Müeller Hinton broth for bacteria or RPMI 1640 for Candida albicans. At the end, 96-well microtiter plates were labeled and covered in polyethylene bags to avoid volatilization of the samples. The microtiter plates were incubated at $37^{\circ} \mathrm{C}$ for $24 \mathrm{~h}$ under aerobic conditions. It was performed visually and any change in color from purple (resazurin) to pink resorufin was considered a positive result. MIC values are defined as the lowest concentration of essential oil that prevents a color change of resazurin. The average of three values were calculated and reported as the MIC. For the result interpretation, the parameters of Holetz et al [63] were considered as follows: Inactive $>1000 \mu \mathrm{g} / \mathrm{mL}$, Weak activity 500 to $1000 \mu \mathrm{g} / \mathrm{mL}$, moderate activity 100 to $<500 \mu \mathrm{g} / \mathrm{mL}$, good activity $<100 \mu \mathrm{g} / \mathrm{mL}$. 


\subsection{Statistical Treatment}

The results were subjected to an analysis of variance (ANOVA) followed by the Dunnet test. It is considered a significant difference when $P$ values is less than 0.05 .

\section{Conclusions}

Based on the obtained results, it can be concluded that the three essential oils from Croton are richest in hydrocarbons, monoterpenes, and hydrocarbons and oxygenated sesquiterpenes. In addition to the main bioactive compounds, $C$ adipatus is rich in $\beta$ Myrcene (18.34\%), $\mathrm{C}$ thurifer in an unknown monoterpene $\left(\mathrm{C}_{10} \mathrm{H}_{16}\right)$ with $22.38 \%$ and C. collinus in $\beta$-caryophyllene (44.7\%). Our research showed C. adipatus was selective for B. subtilis and C. albicans, C. thurifer for S. aureus. while C. collinus exhibited their antimicrobial activity towards B. subtilis and C. albicans. Although results showed some potential in the in vitro assay, these still may not be applied in vivo. Further research in in vivo models is necessary to evaluate the antimicrobial activity of these essential oils.

Supplementary Materials: The following are available online at https: / www.mdpi.com/article / 10.3390/antibiotics10111387/s1, Figure S1: GC-MS chromatogram of the essential oil of Croton adipatus Kunth; Figure S2: Spectrum of the main constituents of the essential oil of Croton adipatus Kunth. A: $\beta$-myrcene; B: $\alpha$-thujene; C: D-limonene; Figure S3: GC-MS chromatogram of the essential oil of Croton thurifer Kunth; Figure S4: Spectrum of the main constituents of the essential oil of Croton thurifer Kunth. A: Unknown $\left(\mathrm{C}_{10} \mathrm{H}_{16}\right)$; B: Unknown $\left(\mathrm{C}_{15} \mathrm{H}_{26} \mathrm{O}\right)$; $\mathrm{C}$ : $\beta$-elemene; Figure S5: GC-MS chromatogram of the essential oil of Croton collinus Kunth; Figure S6: Spectrum of the main constituents of the essential oil of Croton collinus Kunth. A: $\beta$-caryophyllene B: D-limonene; C: $\beta$-thujene; Figure S7: Determination of the Minimum Inhibitory Concentration of the standard drugs; Table S1: Physicochemical properties of the essential oils of Croton species. Table S1: Chemical composition of Croton adipatus Kunth essential oil; Table S2: Chemical composition of Croton thurifer Kunth essential oil. Table S3: Chemical composition of Croton collinus Kunth essential oil.

Author Contributions: Conceptualization, J.L.L.C.-M and S.W.M.-B.; methodology, M.E.S.-S..; software, J.L.L.C.-M; validation, C.M.F.-R, and M.E.S.-S; formal analysis, S.W.M.-B; investigation, M.E.S.-S; resources, M.E.S.-S; writing—original draft preparation, O.H.-C; writing—review and editing, O.H.C; visualization, O.H.-C.; supervision, C.M.F.-R.; project administration, J.L.L.C.-M. and S.W.M.-B.; funding acquisition, M.E.S.-S. All authors have read and agreed to the published version of the manuscript.

Funding: This research received no external funding.

Institutional Review Board Statement: Not applicable.

Informed Consent Statement: Not applicable.

Data Availability Statement: The data that support the findings of this study are available from the corresponding author upon reasonable request.

Acknowledgments: The authors thank Biologist Jose Campos for providing us with the taxonomic classification of Croton species.

Conflicts of Interest: The authors declare no conflict of interest.

\section{References}

1. Beraud, G. Shortages Without Frontiers: Antimicrobial Drug and Vaccine Shortages Impact Far Beyond the Individual! Front. Med. 2021, 8, 46. [CrossRef]

2. Abubakar, A.R.; Haque, M. Preparation of medicinal plants: Basic extraction and fractionation procedures for experimental purposes. J. Pharm. Bioallied Sci. 2020, 12, 1-10. [CrossRef]

3. Chouhan, S.; Sharma, K.; Guleria, S. Antimicrobial Activity of Some Essential Oils-Present Status and Future Perspectives. Medicines 2017, 4, 58. [CrossRef]

4. Raut, J.S.; Karuppayil, S.M. A status review on the medicinal properties of essential oils. Ind. Crop. Prod. 2014, 62, 250-264. [CrossRef]

5. Zinngrebe, Y. Learning from local knowledge in Peru-Ideas for more effective biodiversity conservation. J. Nat. Conserv. 2016, 32, 10-21. [CrossRef] 
6. Leon, B.; Riina, R.; Berry, P. Euphorbiaceae endémicas del Perú. Rev. Peru. Biol. 2013, 13, 295s-301s. [CrossRef]

7. Berry, P.E.; Hipp, A.L.; Wurdack, K.J.; van Ee, B.; Riina, R. Molecular phylogenetics of the giant genus Croton and tribe Crotoneae (Euphorbiaceae sensu stricto) using ITS and TRNL-TRNF DNA sequence data. Am. J. Bot. 2005, 92, 1520-1534. [CrossRef] [PubMed]

8. Barrera, C.A.C.; Gómez, D.C.; Castiblanco, F.A. Medicinal Importance of Croton Genus (Euphorbiaceae). Rev. Cuba. Plantas Med. 2016, 21, 234-247.

9. Xu, W.-H.; Liu, W.-Y.; Liang, Q. Chemical Constituents from Croton Species and Their Biological Activities. Molecules 2018, 23, 2333. [CrossRef]

10. Salatino, A.; Salatino, M.L.F.; Negri, G. Traditional uses, chemistry and pharmacology of Croton species (Euphorbiaceae). J. Braz. Chem. Soc. 2007, 18, 11-33. [CrossRef]

11. De Araújo, A.C.J.; Freitas, P.R.; Barbosa, C.R.D.S.; Muniz, D.F.; Rocha, J.E.; Neto, J.B.D.A.; Da Silva, M.M.C.; Moura, T.F.; Pereira, R.L.S.; Ribeiro-Filho, J.; et al. Essential Oil of Croton ceanothifolius Baill. Potentiates the Effect of Antibiotics against Multiresistant Bacteria. Antibiotics 2020, 9, 27. [CrossRef]

12. Filho, J.M.T.D.A.; Araújo, L.D.C.; Oliveira, A.P.; Guimarães, A.L.; Pacheco, A.G.; Silva, F.; Cavalcanti, L.S.; Lucchese, A.; Almeida, J.R.D.S.; Araujo, E.C.D.C. Chemical composition and antibacterial activity of essential oil from leaves of Croton heliotropiifolius in different seasons of the year. Rev. Bras. Farm. 2017, 27, 440-444. [CrossRef]

13. de Araújo, L.G.; Veras, G.; Alves, J.V.D.O.; de Veras, B.O.; da Silva, M.V.; Rodrigues, J.F.B.; Fook, M.V.L.; Amoah, S.K.S.; Torres, M.C.D.M. Chemodiversity and Antibacterial Activity of the Essential Oil of Leaves of Croton argyrophyllus. Chem. Biodivers. 2020, 17, e2000575. [CrossRef]

14. Morais, S.M.; Cavalcanti, E.S.; Bertini, L.M.; Oliveira, C.L.; Rodrigues, J.R.; Cardoso, J.H. Larvicidal Activity of Essential Oils from Brazilian Croton Species against Aedes aegypti L. J. Am. Mosq. Control Assoc. 2006, 22, 161-164. [CrossRef]

15. Dória, G.; Silva, W.J.; Carvalho, G.A.; Alves, P.; Cavalcanti, S.C.H. A study of the larvicidal activity of two Crotonspecies from northeastern Brazil against Aedes aegypti. Pharm. Biol. 2010, 48, 615-620. [CrossRef] [PubMed]

16. Ruphin, F.P.; Baholy, R.; Sylver, S.; Oscar, R.A.Y.; Mahamoud, A.; Raymond, F.F.; Marcelin, S.; Rakotoniriana, H.J.; Amelie, R. GC-FID and GC/MS Analyses and Antimicrobial Activity of Croton Greveanus, C. Borarium and C. Geayi (Euphorbiaceae) Essential Oils from Madagascar. J. Pharmacogn. Phytochem. 2016, 5, 188-197.

17. Ogundajo, A.L.; Ogunwande, I.A.; Gbadamosi, H.G.; Giwa, R.; Flamini, G. Chemical Composition of the Leaf Essential Oils of Croton zambesicus Müll.-Arg. Grown in Lagos, South-West Nigeria. Eur. J. Med. Plants 2014, 4, 1524-1533. [CrossRef]

18. Azevedo, M.M.B.; Chaves, F.C.M.; Almeida, C.A.; Bizzo, H.R.; Duarte, R.S.; Campos-Takaki, G.M.; Alviano, C.S.; Alviano, D.S. Antioxidant and Antimicrobial Activities of 7-Hydroxy-calamenene-Rich Essential Oils from Croton cajucara Benth. Molecules 2013, 18, 1128-1137. [CrossRef]

19. Moreno, P.R.H.; Lima, M.E.L.; Caruzo, M.B.R.; Carneiro-Torres, D.; Cordeiro, I.; Young, M.C.M. Chemical Composition and Antimicrobial Activity of the Essential Oil from Croton heterocalyx Baill. (Euphorbiaceae s.s.) Leaves. J. Essent. Oil Res. 2009, 21, 190-192. [CrossRef]

20. Peixoto, R.N.S.; Guilhon, G.M.S.P.; Zoghbi, M.D.G.B.; Araújo, I.S.; Uetanabaro, A.P.T.; Santos, L.S.; Brasil, D.D.S.B. Volatiles, A Glutarimide Alkaloid and Antimicrobial Effects of Croton pullei (Euphorbiaceae). Molecules 2013, 18, 3195-3205. [CrossRef]

21. de Almeida, T.S.; da Rocha, J.B.T.; Rodrigues, F.F.G.; Campos, A.R.; da Costa, J.G.M. Chemical composition, antibacterial and antibiotic modulatory effect of Croton campestris essential oils. Ind. Crop. Prod. 2013, 44, 630-633. [CrossRef]

22. Melo, G.F.D.A.; Da Costa, A.C.V.; Garino, F.; Medeiros, R.S.; Madruga, M.S.; Neto, V.Q. The sensitivity of bacterial foodborne pathogens to Croton blanchetianus Baill essential oil. Braz. J. Microbiol. 2013, 44, 1189-1194. [CrossRef] [PubMed]

23. Athikomkulchai, S.; Tadtong, S.; Ruangrungsi, N.; Hongratanaworakit, T. Chemical Composition of the Essential Oil from Croton Oblongifolius and its Antibacterial Activity Against Propionibacterium Acnes. Nat. Prod. Commun. 2015, 10, 1459-1460. [CrossRef] [PubMed]

24. De Heluani, C.S.; De Lampasona, M.P.; Vega, M.I.; Catalan, C.A. Antimicrobial Activity and Chemical Composition of the Leaf and Root Oils fromCroton hieronymiGriseb. J. Essent. Oil Res. 2005, 17, 351-353. [CrossRef]

25. Yang, L.; Wen, K.-S.; Ruan, X.; Zhao, Y.-X.; Wei, F.; Wang, Q. Response of Plant Secondary Metabolites to Environmental Factors. Molecules 2018, 23, 762. [CrossRef]

26. De, I.; Neves, A.; da Camara, C.A.G. Volatile Constituents of Two Croton Species from Caatinga Biome of Pernambuco-Brasil. Nat. Prod. 2012, 6, 161-165.

27. Dai, D.N.; Huong, L.T.; Thang, T.D.; Ogunwande, I.A. Chemical Constituents of Essential Oils of the Leaves of Three Species of Croton from Vietnam. Chem. Nat. Compd. 2014, 50, 155-157. [CrossRef]

28. Turiel, N.A.; Ribeiro, A.F.; Carvalho, E.; Domingos, V.D.; Lucas, F.C.A.; Carreira, L.M.M.; Andrade, E.H.D.A.; Maia, J.G.S. Essential Oils Composition of Croton Species from the Amazon. Nat. Prod. Commun. 2013, 8, 1471-1472. [CrossRef]

29. Radulovic, N.; Mananjarasoa, E.; Harinantenaina, L.; Yoshinori, A. Essential oil composition of four Croton species from Madagascar and their chemotaxonomy. Biochem. Syst. Ecol. 2006, 34, 648-653. [CrossRef]

30. Santos, G.K.; Dutra, K.A.; Lira, C.S.; Lima, B.N.; Napoleão, T.H.; Paiva, P.M.; Maranhão, C.A.; Brandão, S.S.; Navarro, D.M. Effects of Croton rhamnifolioides essential oil on Aedes aegypti oviposition, larval toxicity and trypsin activity. Molecules 2014, 19, 16573-16587. [CrossRef] 
31. Rojas, J.; Buitrago, A.; Rojas, L.B.; Cárdenas, J.; Carmona, J. Chemical Composition of the Essential Oil of Croton huberi Steyerm. (Euphorbiaceae) Collected from Tachira-Venezuela. J. Essent. Oil Bear. Plants 2013, 16, 646-650. [CrossRef]

32. da Silva Almeida, J.R.G.; de Souza, A.V.V.; de Oliveira, A.P.; dos Santos, U.S.; de Souza, M.D.; Bispo, L.P.; Turatti, I.C.C.; Lopes, N.P. Chemical composition of essential oils from the stem barks of Croton conduplicatus (Euphorbiaceae) native to the Caatinga biome. Afr. J. Pharm. Pharmacol. 2015, 9, 98-101. [CrossRef]

33. Jaramillo-Colorado, B.; Duarte-Restrepo, E.; Jaimes, L. Bioactividad Del Aceite Esencial de Croton Trinitatis Millsp Colombiano. Bol. Latinoam. Caribe Plantas Med. Aromát. 2016, 15, 249-257.

34. Vunda, S.L.L.; Sauter, I.P.; Cibulski, S.P.; Roehe, P.; Bordignon, S.A.L.; Rott, M.; Apel, M.A.; Von Poser, G.L. Chemical composition and amoebicidal activity of Croton pallidulus, Croton ericoides, and Croton isabelli(Euphorbiaceae) essential oils. Parasitol. Res. 2012, 111, 961-966. [CrossRef] [PubMed]

35. Yagi, S.; Babiker, R.; Tzanova, T.; Schohn, H. Chemical composition, antiproliferative, antioxidant and antibacterial activities of essential oils from aromatic plants growing in Sudan. Asian Pac. J. Trop. Med. 2016, 9, 763-770. [CrossRef] [PubMed]

36. Andrade, T.C.; De Lima, S.G.; Freitas, R.M.; Rocha, M.S.; Islam, M.; Da Silva, T.G.; Militão, G.C. Isolation, characterization and evaluation of antimicrobial and cytotoxic activity of estragole, obtained from the essential oil of croton zehntneri (euphorbiaceae). Anais Acad. Bras. Ciências 2015, 87, 173-182. [CrossRef]

37. de Souza, A.V.V.; de Britto, D.; dos Santos, U.S.; Bispo, L.D.P.; Turatti, I.C.C.; Lopes, N.P.; de Oliveira, A.P.; Almeida, J.R.G.D.S. Influence of season, drying temperature and extraction time on the yield and chemical composition of 'marmeleiro' (Croton sonderianus) essential oil. J. Essent. Oil Res. 2017, 29, 76-84. [CrossRef]

38. Dourado, R.C.; Silveira, E.R. Preliminary Investigation on the Volatile Constituents ofCroton sonderianusMuell. Arg.: Habitat, Plant Part and Harvest Time Variation. J. Essent. Oil Res 2005, 17, 36-40. [CrossRef]

39. Lawal, O.A.; Ogunwande, I.A.; Osunsanmi, F.O.; Opoku, A.R.; Oyedeji, A.O. Croton gratissimus Leaf Essential Oil Composition, Antibacterial, Antiplatelet Aggregation, and Cytotoxic Activities. J. Herbs Spices Med. Plants 2016, 23, 77-87. [CrossRef]

40. Hyldgaard, M.; Mygind, T.; Meyer, R.L. Essential Oils in Food Preservation: Mode of Action, Synergies, and Interactions with Food Matrix Components. Front. Microbiol. 2012, 3, 12. [CrossRef]

41. Moo, C.-L.; Yang, S.-K.; Osman, M.-A.; Yuswan, M.H.; Loh, J.-Y.; Lim, W.-M.; Lim, S.-H.-E.; Lai, K.-S. Antibacterial Activity and Mode of Action of $\beta$-caryophyllene on Bacillus cereus. Pol. J. Microbiol. 2020, 69, 49-54. [CrossRef]

42. Han, Y.; Chen, W.; Sun, Z. Antimicrobial activity and mechanism of limonene against Staphylococcus aureus. J. Food Saf. 2021, 41, e12918. [CrossRef]

43. Pereira, F.G.; Marquete, R.; Domingos, L.T.; Rocha, M.E.; Ferreira-Pereira, A.; Mansur, E.; Moreira, D.L. Antifungal activities of the essential oil and its fractions rich in sesquiterpenes from leaves of Casearia sylvestris Sw. Anais Acad. Bras. Ciências 2017, 89, 2817-2824. [CrossRef] [PubMed]

44. Araújo, F.M.; Dantas, M.C.; e Silva, L.S.; Aona, L.; Tavares, I.F.; de Souza-Neta, L.C. Antibacterial activity and chemical composition of the essential oil of Croton heliotropiifolius Kunth from Amargosa, Bahia, Brazil. Ind. Crop. Prod. 2017, 105, 203-206. [CrossRef]

45. Leite, T.R.; Da Silva, M.A.P.; Dos Santos, A.C.B.; Coutinho, H.D.M.; Duarte, A.E.; Da Costa, J.G.M. Antimicrobial, modulatory and chemical analysis of the oil of Croton limae. Pharm. Biol. 2017, 55, 2015-2019. [CrossRef]

46. Nazzaro, F.; Fratianni, F.; DE Martino, L.; Coppola, R.; De Feo, V. Effect of Essential Oils on Pathogenic Bacteria. Pharmaceuticals 2013, 6, 1451-1474. [CrossRef]

47. Burt, S. Essential oils: Their antibacterial properties and potential applications in foods-A review. Int. J. Food Microbiol. 2004, 94, 223-253. [CrossRef]

48. Li, L.; Li, Z.-W.; Yin, Z.-Q.; Wei, Q.; Jia, R.-Y.; Zhou, L.-J.; Xu, J.; Song, X.; Zhou, Y.; Du, Y.-H.; et al. Antibacterial activity of leaf essential oil and its constituents from Cinnamomum longepaniculatum. Int. J. Clin. Exp. Med. 2014, 7, 1721-1727.

49. Marinas, I.; Oprea, E.; Buleandra, M.; Badea, I.; Tihauan, B.; Marutescu, L.; Angheloiu, M.; Matei, E.; Chifiriuc, M. Chemical Composition, Antipathogenic and Cytotoxic Activity of the Essential Oil Extracted from Amorpha fruticosa Fruits. Molecules 2021, 26, 3146. [CrossRef]

50. Dahham, S.S.; Tabana, Y.M.; Iqbal, M.A.; Ahamed, M.B.K.; Ezzat, M.O.; Majid, A.S.A.; Majid, A.M.S.A. The Anticancer, Antioxidant and Antimicrobial Properties of the Sesquiterpene $\beta$-Caryophyllene from the Essential Oil of Aquilaria crassna. Molecules 2015, 20, 11808-11829. [CrossRef]

51. Sieniawska, E.; Sawicki, R.; Golus, J.; Swatko-Ossor, M.; Ginalska, G.; Skalicka-Wozniak, K. Nigella damascena L. Essential Oil—A Valuable Source of $\beta$-Elemene for Antimicrobial Testing. Molecules 2018, 23, 256. [CrossRef] [PubMed]

52. Montanari, R.M.; Barbosa, L.C.A.; Demuner, A.J.; Silva, C.; Carvalho, L.S.; Andrade, N.J. Chemical composition and antibacterial activity of essential oils from verbenaceae species: Alternative sources of (E)-caryophyllene and germacrene-D. Quimica Nova 2011, 34, 1550-1555. [CrossRef]

53. Marchese, A.; Arciola, C.R.; Barbieri, R.; Silva, A.S.; Nabavi, S.M.; Sokeng, A.J.T.; Izadi, M.; Jafari, N.J.; Suntar, I.; Daglia, M.; et al. Update on Monoterpenes as Antimicrobial Agents: A Particular Focus on p-Cymene. Materials 2017, 10, 947. [CrossRef] [PubMed]

54. Dob, T.; Dahmane, D.; Benabdelkader, T.; Chelghoum, C. Composition and Antimicrobial Activity of the Essential Oil ofThymus fontanesii. Pharm. Biol. 2006, 44, 607-612. [CrossRef] 
55. Połeć, K.; Broniatowski, M.; Wydro, P.; Hac-Wydro, K. The impact of $\beta$-myrcene - the main component of the hop essential oil on the lipid films. J. Mol. Liq. 2020, 308, 113028. [CrossRef]

56. Da Silva, A.C.R.; Lopes, P.M.; Azevedo, M.; Costa, D.C.M.; Alviano, C.S.; Alviano, D.S. Biological Activities of a-Pinene and $\beta$-Pinene Enantiomers. Molecules 2012, 17, 6305-6316. [CrossRef]

57. Herman, A.; Tambor, K.; Herman, A.P. Linalool Affects the Antimicrobial Efficacy of Essential Oils. Curr. Microbiol. 2015, 72, 165-172. [CrossRef] [PubMed]

58. Işcan, G.; Kırımer, N.; Demirci, F.; Demirci, B.; Noma, Y.; Başer, K.H.C. Biotransformation of (-)-(R)- $\alpha$-Phellandrene: Antimicrobial Activity of Its Major Metabolite. Chem. Biodivers. 2012, 9, 1525-1532. [CrossRef]

59. Rojas-Armas, J.P.; Arroyo-Acevedo, J.L.; Palomino-Pacheco, M.; Herrera-Calderón, O.; Sanchez, J.M.O.; Rojas-Armas, A.; Calva, J.; Castro-Luna, A.; Hilario-Vargas, J. The Essential Oil of Cymbopogon citratus Stapt and Carvacrol: An Approach of the Antitumor Effect on 7,12-Dimethylbenz-[ $\alpha$ ]-anthracene (DMBA)-Induced Breast Cancer in Female Rats. Molecules 2020, 25, 3284. [CrossRef]

60. Rojas, R.; Bustamante, B.; Bauer, J.; Fernández, I.; Alban, J.; Lock, O. Antimicrobial activity of selected Peruvian medicinal plants. J. Ethnopharmacol. 2003, 88, 199-204. [CrossRef]

61. CLSI. M07: Dilution AST for Aerobically Grown Bacteria. Available online: https://clsi.org/standards/products/microbiology/ documents / $\mathrm{m} 07 /$ (accessed on 15 October 2021).

62. Liu, M.; Seidel, V.; Katerere, D.; Gray, A.I. Colorimetric broth microdilution method for the antifungal screening of plant extracts against yeasts. Methods 2007, 42, 325-329. [CrossRef] [PubMed]

63. Holetz, F.B.; Pessini, G.L.; Sanches, N.R.; Cortez, D.A.G.; Nakamura, C.V.; Filho, B.P.D. Screening of some plants used in the Brazilian folk medicine for the treatment of infectious diseases. Memórias Inst. Oswaldo Cruz 2002, 97, 1027-1031. [CrossRef] [PubMed] 